\title{
Management protocol for dental outpatient department during the COVID-19 pandemic: documenting best practices
}

\author{
Jing Guo ${ }^{1}$, Kun XUAN ${ }^{1}$, LingXia GUAN ${ }^{1}$, ZiHan $\mathrm{LI}^{1}$, Liang KONG${ }^{1}$, and Ming ZHANG ${ }^{1}$ \\ ${ }^{1}$ State Key Laboratory of Military Stomatology \& National Clinical Research Center for \\ Oral Diseases \& Shaanxi Clinical Research Center for Oral Diseases, School of \\ Stomatology, The Fourth Military Medical University
}

June 28, 2020

\begin{abstract}
Objectives: The ongoing outbreak of novel coronavirus (2019-nCoV) infection (COVID-19) has been declared as a global pandemic by the World Health Organization. It is a highly contagious disease that poses a grave threat to human health. Dental practice involves close contact with the airway and dental procedures entail generation of intense aerosol sprays; the virus particles can survive within small droplets in the air for several hours. Thus, dental practice is associated with a high risk of cross infection. This article describes the patient management process and its performance at the outpatient department of a specialized dental hospital during the COVID-19 epidemic in Xi'an, China. The objective is to provide a reference for management protocols for dental clinics and dental specialty centers across the world. Methods: A specialized management protocol for staff, patients, and material management for dental clinic during the epidemic was implemented since February 3 2020. The numbers of outpatient visits, distribution of oral diseases, demographic characteristics of patients, and COVID-19 infection among patients and staff from February 3 to March 15 are described. Results: The management protocols at the dental clinic were tailored according to the level of national emergency response for COVID-19. The number of physical consultations at the hospital was effectively controlled with use of online consulting service. Dental emergency patients were managed safely. Conclusion: The management protocol and infection prevention and control strategies adopted at our institution are effective in treating dental emergencies while controlling the spread of COVID-19 virus in oral clinics.
\end{abstract}

\begin{abstract}
Objectives : The ongoing outbreak of novel coronavirus (2019-nCoV) infection (COVID-19) has been declared as a global pandemic by the World Health Organization. It is a highly contagious disease that poses a grave threat to human health. Dental practice involves close contact with the airway and dental procedures entail generation of intense aerosol sprays; the virus particles can survive within small droplets in the air for several hours. Thus, dental practice is associated with a high risk of cross infection.

This article describes the patient management process and its performance at the outpatient department of a specialized dental hospital during the COVID-19 epidemic in Xi'an, China. The objective is to provide a reference for management protocols for dental clinics and dental specialty centers across the world.

Methods : A specialized management protocol for staff, patients, and material management for dental clinic during the epidemic was implemented since February 3 2020. The numbers of outpatient visits, distribution of oral diseases, demographic characteristics of patients, and COVID-19 infection among patients and staff from February 3 to March 15 are described.
\end{abstract}

Results : The management protocols at the dental clinic were tailored according to the level of national emergency response for COVID-19. The number of physical consultations at the hospital was effectively controlled with use of online consulting service. Dental emergency patients were managed safely. 
Conclusion : The management protocol and infection prevention and control strategies adopted at our institution are effective in treating dental emergencies while controlling the spread of COVID-19 virus in oral clinics.

Key words: Dental practice management; dental infection control; outpatient clinics; Urgent care clinics; public health dentistry; Remote consultation

\section{Introduction}

On December 31, 2019, the World Health Organization (WHO) was alerted to several cases of pneumonia of unknown etiology in Wuhan, the capital city of Hubei Province in Central China ${ }^{1}$. On January 8, 2020, the Chinese authorities identified the causative agent as a novel coronavirus (2019-nCoV). The China Center for Disease Control (CDC) has named the associated disease as novel coronavirus-infected pneumonia (NCIP) 2. The WHO declared the 2019-nCoV outbreak as a Public Health Emergency of International Concern on January 30 and as a Global Pandemic on March $12^{3}$. As of June 26 2020, more than 9.6 million confirmed cases have been reported from across the globe, with a death toll of 489405 . Prevention and control of the global epidemic poses a grave challenge to humanity ${ }^{4}$.

Xi'an is the capital of Shaanxi province, which is located in the northwestern region of China and borders the northwestern area of Hubei province. The city has a population of approximately 10 million. The first confirmed case in Xi'an was reported on January 3. However, due to prudent prevention measures instituted by the Chinese health authorities, the disease has been controlled well. No new confirmed or suspected cases have been reported in Shaanxi province after February 29. The total number of confirmed cases in Xi'an reached 120 by the end of March 15, while the number of close contacts of confirmed cases was $9296{ }^{5}$. The Government of Xi'an launched the first level emergency response to the COVID-19 outbreak on January 25 ${ }^{6}$; subsequently, the emergency response was downgraded from the first level to the third level on February $28^{7}$.

Due to the characteristics of dental settings, there is a high risk of cross-infection between dental practitioners and patients ${ }^{8}$. Therefore, institution of meticulous infection control protocols for dental health-care personnel (DHCP) is a key imperative in all countries/regions that are potentially affected by COVID-19. The Affiliated stomatology hospital of the Fourth Military Medical University is an internationally acclaimed dental specialty center (DSC). It is the one of main institutions that dealt with dental emergencies during the COVID-19 epidemic in Xi'an. This article describes the management procedures and operational protocol followed at the DSC outpatient department during the COVID-19 epidemic in Xi 'an, China. The objective is to provide a reference for management protocols for dental clinics and dental specialty centers across the world.

\section{Methods}

DHCP include dentists, dental assistants, dental laboratory technicians (in-office and commercial), contractual personnel, and other persons who are not directly involved in patient care, but are potentially exposed to infectious agents ${ }^{9}$. All specialized dental health-care procedures were performed in pre-specified areas with appropriate personal protective equipment (PPE) ${ }^{10}$. (Table 1 and Figure 1)

Dental outpatient services were only focused on dental emergency visits, while the departments that are not related to emergency operations were closed. DHCP were minimized as much as possible to avoid nosocomial infection. Hospital remote consultation system was used to diagnose complex cross-specialty oral diseases. In addition, all DHCPs were screened prior to their entry into the outpatient department, and used an elevator exclusively dedicated to DHCPs to obtain PPE and perform tasks. All DHCP were adequately trained in the appropriate use of PPE to maximize compliance.

Dental services were limited to emergency visits only during the period of the pandemic. This helped ensure safety of staff and patients, preserved personal protective equipment and patient care supplies, and helped 
expand the available health system capacity. Elective procedures, surgeries, and non-urgent dental visits were postponed.

The dental outpatient official website published the 'Notice of dental health care during COVID-19 pandemic' in advance, to inform patients about postponement of elective procedures, surgeries, and non-urgent dental visits. A mobile health counseling system was used by dentists to obtain remote access to dental information and images and provide dental recommendations. This approach helped prioritize high-risk patients, provided them with a quick treatment pathway, and avoided unnecessary travel. Only urgent dental visits were permitted in the emergency department.

The dental service procedure for patients was designed in three aspects: service time stages, service regions, and DHCP (Table 1 and Figure 1). All DHCPs strictly adhered to standard precautions including hand hygiene.

Prior to treatment, all patients underwent a preliminary screening including temperature measurement on two occasions. Patients may use a built-in WeChat program or a mobile phone application developed by the public service and government affairs platform in Xi'an to complete the health condition report; this results in the generation of a two-dimensional code. Only passengers with a green code are allowed to travel, which implies that people had little chance of having been infected before entering the outpatient clinic ${ }^{11}$. After entering the outpatient department, spatial distance of at least 1 meter was mandatory (Table 1 and Figure $1)$.

Dental settings have unique characteristics that warrant additional infection control considerations. Routine dental clinic area is suggested to be isolated. The height of physical partition should not be less than 180 $\mathrm{cm}$. Patients were required to wear PPE such as disposable caps and shoe covers. Antiseptic hand rub was performed by everyone. Isolated splash treatment areas were set at the end of routine dental clinic area for dental emergencies ${ }^{12,13}$.

Before leaving the general treatment area, patients took off their PPE and were provided a new medical mask before their exit from the area. They were required to wear a new medical mask prior to their exit from the splash treatment area. The surface, supplies, and/or equipment located within 6 feet of symptomatic patients were cleaned, disinfected, or discarded. All disinfection procedures were performed according to the Guidelines for Infection Control in Dental Health-Care Settings-2003 ${ }^{14}$. An interval time of at least 10 minutes was maintained between each patient ${ }^{8} . t$

To ensure the integrity and rapidity of material allocation during the pandemic, three areas to deliver medical supplies were set up: first, for standard protective equipment; second, for PPE; third, for dental care materials. DHCP were equipped with PPE before starting work (Figure 2-A). All medical supplies were stocked by the material management department of the hospital on a regular basis as required.

A schematic illustration of the procedures for recycling and disposal of medical supplies is presented in Figure $2 \mathrm{~B}$.

Combined with the COVID-19 confirmed cases and the epidemic policy in Xi'an, the daily patients before and during the pandemic are described. The patients flow control performance, dental emergency visit categories, and the age and sex distribution of patients with pulpal and periapical diseases and dental trauma are described.

All DHCPs in the outpatient department underwent daily measurement of body temperature. The outcomes of dental treatment and the COVID-19 relevant health conditions were inquired and recorded on the second and the fourteenth day after treatment.

\section{Results}

The Stomatological Hospital of the Forth Military Medical University has about 400 DHCPs; only $5 \%$ of the DHCPs provided dental health services during the pandemic. Strict outpatient management procedures 
were implemented to safeguard all patients and DHCP.

From February 3 to March 15, 3317 people (56.37\%) received online health consultation and 2567 patients $(43.63 \%)$ had dental visits. Before the pandemic, the number of dental visits per day was approximately 725 on weekdays and about 294 on weekend. During the level I response to the public health emergency (February $3-28,2020$ ), the number of patients decreased to 16 , which was only $2.21 \%$ of the daily dental visits in the week before the pandemic. Since the level I response was restored to level III on February 29, the return rate of medical staff increased to $20 \%$; the numbers of dental visits per day gradually increased to 104 , which was $14.34 \%$ of the daily dental visits during the week before the pandemic (Figure 3 ).

Approximately 5884 patients used mobile health APP for online dental consultation (Figure 4A). In addition, 2567 patients made dental visits through online appointment. $20.80 \%$ of dental visits, which were elective procedures and surgeries, were postponed. The remaining $79.20 \%$ patients entered into the routine dental clinic areas. Only 125 patients underwent splash treatment.

Figure $4 \mathrm{~B}$ shows the reasons for outpatient dental visits. These included: pulpal and periapical pain (27.35\%); mucosal diseases (14.71\%); orthodontic treatment (11.85\%); pericoronitis $(10.92 \%)$; caries $(10.03 \%)$, maxillofacial surgery-related diseases $(9.39 \%)$; tooth trauma $(7.58 \%)$; others $(8.17 \%)$ (including periodontal diseases, prosthetic related diseases, temporomandibular joint diseases). $22.48 \%$ of patients with pulpal and periapical pain required splash treatment.

Figures $4 \mathrm{C}$ and $4 \mathrm{D}$ show the age and sex distribution of patients with pulpitis, periapical periodontitis, and dental trauma, which were the most common causes of dental emergency visits. Pulpitis and periapical periodontitis are the most common dental emergencies; these are more likely to affect people aged 26-40 years and children younger than 10 years. Men and children ([?]6 years) tend to have a higher incidence of dental trauma.

Owing to the meticulous implementation of IPC measures, effective patient triage, and strict protocol for dental procedures, none of the patients were infected with COVID-19 at our hospital during the pandemic.

\section{Discussion}

The COVID-19 was recently identified in saliva of infected patients ${ }^{5}$. Dental clinical procedures are associated with a very high risk of COVID-19 transmission due to generation of droplets and aerosols ${ }^{15}$.

Since laboratory-confirmed cases of COVID-19 may be asymptomatic, there is a need for high level of vigilance in the dental outpatient departments. Healthcare-acquired COVID-19 infection among patients and transmission of infection from patients to healthcare workers is a well-known characteristic of the disease and a leading means of spread ${ }^{16}$. Therefore, in the face of a new infection that is considered highly contagious, it is prudent to review infection control procedures ${ }^{14,17}$. Since the outbreak of COVID-19, nine DHCPs in Wuhan tested positive for the virus. However, there were no documented cases of nosocomial infection of COVID-19 in dental settings ${ }^{18}$. DHCPs must pay adequate attention to IPC measures because of the high prevalence of oral diseases and their highly contagious nature ${ }^{19}$.

The local and national governments in China have taken unprecedented measures in response to the COVID19 outbreak including promotion of physical distancing and encouraging residents to avoid crowded places ${ }^{20}$, such as dental outpatient clinics. We adopted three measures to improve the safety and efficiency of outpatient work. Firstly, we took advantage of mobile technology to acquire dental information and images and to provide remote dental consultations. This approach helped prioritize high-risk patients and provided them with a quick treatment pathway, avoiding unnecessary referrals or travel ${ }^{21}$ (Figure 4A). Secondly, based on the analysis of national and district-level epidemiological data and data modeling, risk-stratification was performed using the nationally recommended three color "health QR codes" - green, yellow, and red. This strategy helped curb the spread of infection as the economic activities were tentatively restarted ${ }^{11}$. Last but not the least, for emergency dental care, meticulous adherence to outpatient management protocol can help minimize the risk of COVID-19 transmission and cluster outbreak in dental settings. 
After a series of measures were implemented, the present study identified at least 5884 residents in Xi'an who attended dental emergency for pain relief or other reasons. Pulpal and periapical pain were responsible for more than a quarter of all emergency dental visits. This trend is similar to that observed in a previous study $^{22} .22 .48 \%$ of these cases required entry to the splash treatment unit, where dental healthcare workers adhered to the appropriate use of PPE and disinfection process. The prevalence of dental trauma was lower than that in the other study owing to the restrictions imposed on public gatherings and outdoor activities. Based on our data (Figure 4B-D), we provide some recommendations. Firstly, close co-operation between endodontist, oral mucosa specialist, orthodontist, periodontist, and pediatric dentist via tele-dentistry is crucial to relieve oral uncomfortable symptoms effectively during the COVID-19 epidemic outbreak. Secondly, oral health promotion in critical age-groups (such as toddlers, preschool children and youth) may help reduce the incidence of dental emergencies related to pulpal and periapical diseases. Enhancing self-protection consciousness for preschool children may help decrease dental trauma during the COVID-19 epidemic outbreak.

Conclusion Formulation of strict, scientific and executable protocols for dental outpatient management played a critical role in promoting safety of oral medical staff and patients at our institution. This work provides valuable reference for dental care settings across the world. Dental outpatient clinic practice management is gradually returning to normal with control of the epidemic.

\section{Acknowledgements}

This study was supported by National Natural Science Foundation of China (grant no: 81900957 and 81701030). The authors declare no potential conflicts of interest with respect to the authorship and/or publication of this article. All authors gave their final approval and agree to be accountable for all aspects of the work. I would like to declare on behalf of my co-authors that the work described was original research that has not been published previously, and not under consideration for publication elsewhere, in whole or in part.

\section{References:}

1. Phelan AL, Katz R, Gostin LO. The Novel Coronavirus Originating in Wuhan, China: Challenges for Global Health Governance. JAMA . 2020;

2. Mahase E. China coronavirus: WHO declares international emergency as death toll exceeds 200. BMJ . 2020;368:m408

3. Coronavirus disease (COVID-19) Pandemic. 2020;2020(2020.03.15)

4. Coronavirus disease (COVID-19) Situation Dashboard. 2020;2020(3.15)

5. To KK, Tsang OT, Chik-Yan YC et al. Consistent detection of 2019 novel coronavirus in saliva. Clin Infect Dis . 2020;

6. Shaanxi launch a public health emergency I level emergency response. 2020;2020(1.25)

7. Adjustion the outbreak emergency response level of COVID-19 in Shaanxi. 2020;2020(1.25)

8. Li ZY, Meng LY. [The prevention and control of a new coronavirus infection in department of stomatology]. Zhonghua Kou Qiang Yi Xue Za Zhi . 2020;55(0):E001

9. Dental Settings Interim Infection Prevention and Control Guidance for Dental Settings During the COVID-19 Response. 2020;2020(April 4)

10. Rational use of personal protective equipment (PPE) for coronavirus disease (COVID-19). 2020;2020(March 19)

11. Health QR code helps curb the spread of COVID-19. 2020;2020(2020.4.20) 
12. Su J. [Aerosol transmission risk and comprehensive prevention and control strategy in dental treatment]. Zhonghua Kou Qiang Yi Xue Za Zhi . 2020;55(0):E006

13. Kobza J, Pastuszka JS, Bragoszewska E. Do exposures to aerosols pose a risk to dental professionals? Occup Med (Lond) . 2018;68(7):454-458

14. Kohn WG CACJ. Guidelines for Infection Control in Dental Health-Care Settings — 2003. $2003 ; 2020(3.15)$

15. Sabino-Silva R, Jardim A, Siqueira WL. Coronavirus COVID-19 impacts to dentistry and potential salivary diagnosis. Clin Oral Investig . 2020;24(4):1619-1621

16. Al-Tawfiq JA, Auwaerter PG. Healthcare-associated infections: the hallmark of Middle East respiratory syndrome coronavirus with review of the literature. J Hosp Infect . 2019;101(1):20-29

17. Samaranayake LP, Peiris M. Severe acute respiratory syndrome and dentistry: a retrospective view. $J$ Am Dent Assoc . 2004;135(9):1292-302

18. Meng L, Hua F, Bian Z. Coronavirus Disease 2019 (COVID-19): Emerging and Future Challenges for Dental and Oral Medicine. J Dent Res . 2020:22034520914246

19. Frichembruder K, Mello DSC, Neves HF. Dental emergency: Scoping review. Plos One . 2020;15(2):e0222248

20. Prem K, Liu Y, Russell TW et al. The effect of control strategies to reduce social mixing on outcomes of the COVID-19 epidemic in Wuhan, China: a modelling study. Lancet Public Health . 2020;

21. Estai M, Kanagasingam Y, Mehdizadeh M et al. Teledentistry as a novel pathway to improve dental health in school children: a research protocol for a randomised controlled trial. Bmc Oral Health . 2020;20(1):11

22. Franciscatto GJ, Brennan DS, Gomes MS, Rossi-Fedele G. Association between pulp and periapical conditions and dental emergency visits involving pain relief: epidemiological profile and risk indicators in private practice in Australia. Int Endod J . 2020;

Fig. 1 Schematic illustration of the patient flow and treatment protocol for dental outpatients during the COVID-19 pandemic

Fig. 2 Procedures for supplies management in dental clinics 


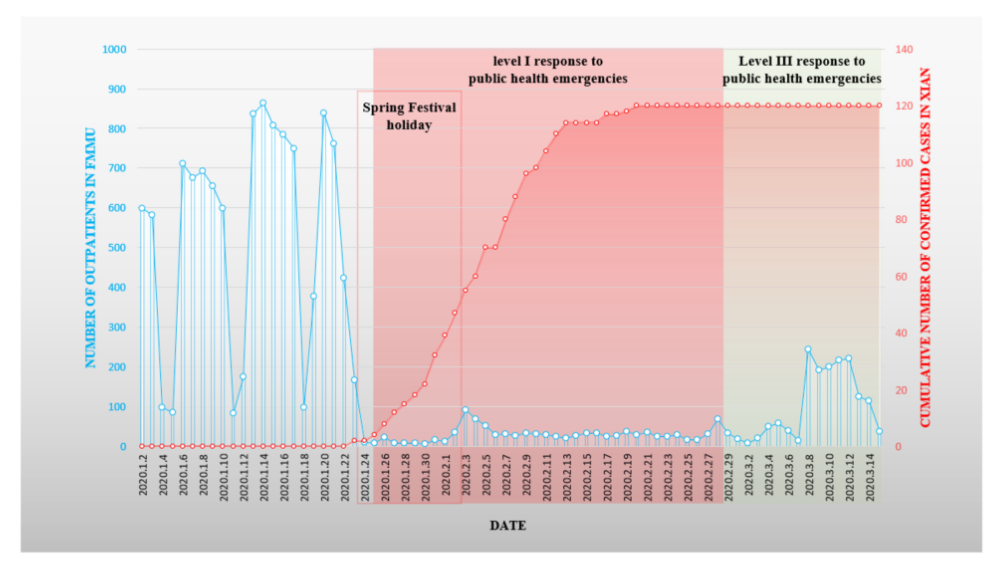

Figure 3. Number of outpatients treated at the Stomatolegy hospital, the Fourth Military Medical University(FMMU), and cumulative number of confirmed cases with coronavirus disease 2019 (COVID-19) in Xian city from January 3, 2019, to March 25, 2020

Fig. 3 Number of daily visits in dental outpatient of the Fourth Military Medical University, and the cumulative number of confirmed cases of coronavirus disease 2019 (COVID-19) in Xi'an city, China, from January 3, 2019, to March 25, 2020

A

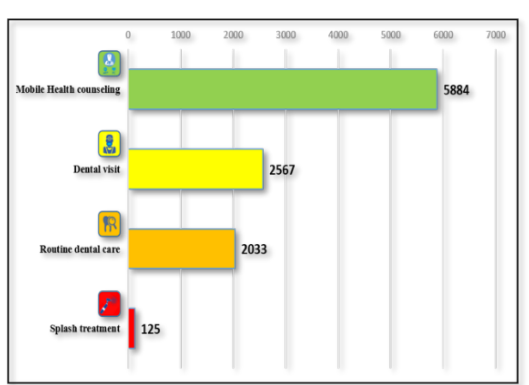

C pulp/periapical disease

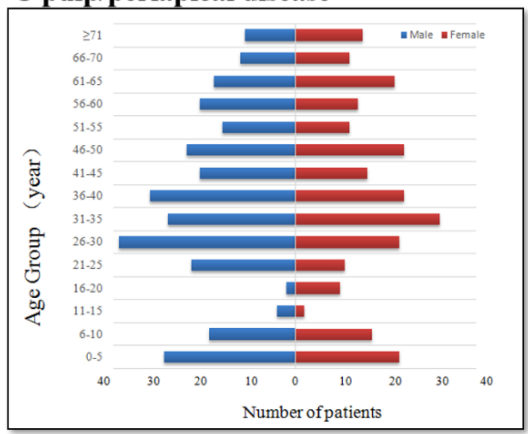

B
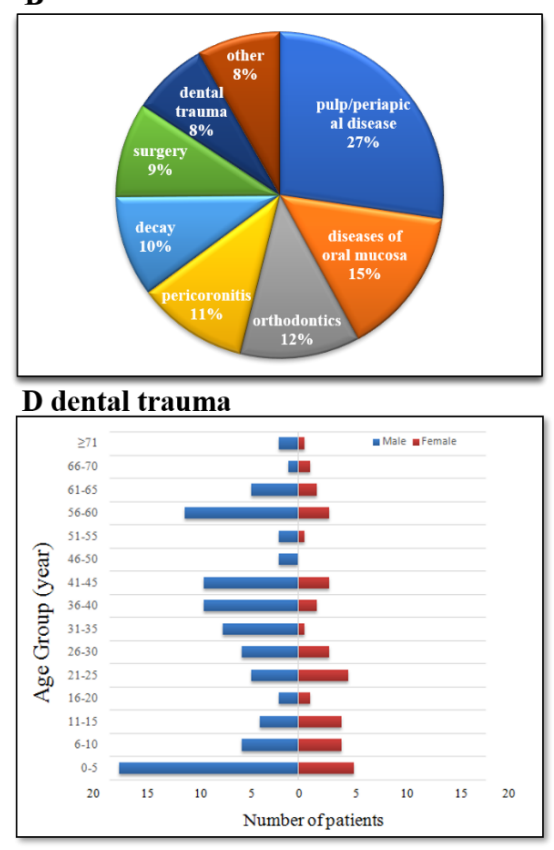
Fig. 4 Documenting the practice of dental emergency visits at the FMMU during the COVID-19 pandemic

A) The patients flow control performance; B) Dental emergency visit categories; C) Age and sex distribution of patients with pulpal and periapical diseases; D) Age and sex distribution of patients with dental trauma.

FMMU, Fourth Military Medical University

Table 1 Dental Outpatient Management Regulations for DHCP according to the Service Stages and Service Areas

Service Service Ar- DHCP

Stages eas description $\mathrm{PPE}^{*}$

Facility for

Epidemic

Disinfection* Responsibilit尹revention Frequency

\begin{tabular}{|c|c|c|c|c|c|c|c|}
\hline \multirow[t]{2}{*}{$\begin{array}{l}\text { Before di- } \\
\text { agnosis }\end{array}$} & $\begin{array}{l}\text { Temperatur } \\
\text { measure- } \\
\text { ment area }\end{array}$ & $\begin{array}{l}\text { Security } \\
\text { personnel }\end{array}$ & $\begin{array}{l}\text { Medical } \\
\text { mask, } \\
\text { Facial pro- } \\
\text { tection }\end{array}$ & $\begin{array}{l}\text { Measure the } \\
\text { temperature of } \\
\text { patients and } \\
\text { their } \\
\text { attendants, ID } \\
\text { registration, } \\
\text { provision of } \\
\text { face mask to } \\
\text { the patient, } \\
\text { and limit the } \\
\text { number of the } \\
\text { accompanying } \\
\text { persons }\end{array}$ & $\begin{array}{l}\text { Infrared } \\
\text { thermometer, } \\
\text { electronic } \\
\text { thermometer, } \\
\text { information } \\
\text { register, hand } \\
\text { sanitizing gel, } \\
\text { chlorine- } \\
\text { containing } \\
\text { disinfectant, } \\
\text { etc. }\end{array}$ & $\begin{array}{l}\text { Twice } \\
\text { day }\end{array}$ & per \\
\hline & $\begin{array}{l}\text { Screen } \\
\text { area }\end{array}$ & Nurses & $\begin{array}{l}\text { Medical } \\
\text { mask, } \\
\text { Gown, } \\
\text { Gloves, } \\
\text { Facial pro- } \\
\text { tection, } \\
\text { Disposable } \\
\text { cap }\end{array}$ & $\begin{array}{l}\text { Gain patient's } \\
\text { epidemic } \\
\text { information } \\
\text { according to } \\
\text { health QR } \\
\text { code, screen } \\
\text { for symptoms } \\
\text { of respiratory } \\
\text { illness (e.g., } \\
\text { fever, cough, } \\
\text { shortness of } \\
\text { breath) }\end{array}$ & $\begin{array}{l}\text { Electronic } \\
\text { thermometer, } \\
\text { precheck triage } \\
\text { list, hand } \\
\text { sanitizing gel, } \\
\text { chlorine- } \\
\text { containing } \\
\text { disinfectant, } \\
\text { etc. }\end{array}$ & $\begin{array}{l}\text { Twice } \\
\text { day }\end{array}$ & per \\
\hline
\end{tabular}


Service Service Ar- DHCP

Stages eas description PPE*
Facility for

Epidemic

ResponsibilitÆrevention Frequency

$\begin{array}{llll}\text { Public area } & \begin{array}{l}\text { Security } \\ \text { personnel }\end{array} & \begin{array}{l}\text { Medical } \\ \text { mask }\end{array} & \begin{array}{l}\text { Guide pa- Hand san- Twice per } \\ \text { tients to itizing gel, day } \\ \text { enter the chlorine- } \\ \text { treatment containing }\end{array} \\ & & \text { area us- disinfec- } \\ \text { ing the tant, etc. } \\ \text { patient- } \\ \text { only ele- } \\ \text { vator or } \\ \text { stairs }\end{array}$

Electronic

During Triage/ Dentist Medical Measure thermometer, Twice per the diag- Registra- and Regis- mask, nosis and tion area trar Gown, treatment
Gloves,

Facial pro-

tection,

Disposable

cap.

the tem-
perature again, triage, registration, fill in informed consent consent for treatment during the outbreak of a major epidemic, hand sanitizing gel, circulating air disinfection machine, chlorinecontaining disinfectant, etc. 
Service

Stages
Service Ar- DHCP

eas description $\mathrm{PPE}^{*}$
Facility for

Epidemic

Responsibilit尹revention
Disinfection*

Frequency

$\begin{array}{lll}\begin{array}{l}\text { Patients } \\ \text { waiting } \\ \text { area }\end{array} & \begin{array}{l}\text { Security } \\ \text { personnel }\end{array} & \begin{array}{l}\text { Medical } \\ \text { mask }\end{array} \\ & & \end{array}$

\begin{tabular}{|c|c|c|c|c|c|c|}
\hline $\begin{array}{l}\text { Routine } \\
\text { dental } \\
\text { clinic area }\end{array}$ & $\begin{array}{l}\text { Dentists } \\
\text { and nurses }\end{array}$ & $\begin{array}{l}\text { Medical } \\
\text { mask, } \\
\text { Gown, } \\
\text { Gloves, } \\
\text { Facial pro- } \\
\text { tection, } \\
\text { Disposable } \\
\text { cap }\end{array}$ & $\begin{array}{l}\text { Oral } \\
\text { examination } \\
\text { (hospital } \\
\text { remote } \\
\text { consultation } \\
\text { system was } \\
\text { used to } \\
\text { diagnose } \\
\text { complex } \\
\text { cross-specialty } \\
\text { oral diseases), } \\
\text { non-splash } \\
\text { treatments, } \\
\text { followed by } \\
\text { oral health } \\
\text { education }\end{array}$ & $\begin{array}{l}\text { Decontamination } \\
\text { film, povidone } \\
\text { iodine gargle, } \\
\text { hand sanitizer, } \\
\text { hand } \\
\text { sanitizing gel, } \\
\text { circulating air } \\
\text { disinfection } \\
\text { machine, } \\
\text { chlorine- } \\
\text { containing } \\
\text { disinfectant, } \\
\text { etc. }\end{array}$ & $\begin{array}{l}\text { Twice } \\
\text { day }\end{array}$ & per \\
\hline $\begin{array}{l}\text { Area for } \\
\text { laboratory } \\
\text { medicine } \\
\text { and imag- } \\
\text { ing }\end{array}$ & $\begin{array}{l}\text { Radiologists } \\
\text { and Lab- } \\
\text { oratory } \\
\text { personnel }\end{array}$ & $\begin{array}{l}\text { Medical } \\
\text { mask, } \\
\text { Gown, } \\
\text { Gloves, } \\
\text { Facial pro- } \\
\text { tection, } \\
\text { Disposable } \\
\text { cap }\end{array}$ & $\begin{array}{l}\text { Biochemical } \\
\text { investi- } \\
\text { gation } \\
\text { of blood } \\
\text { and fluids, } \\
\text { imaging } \\
\text { test, or } \\
\text { patho- } \\
\text { logical } \\
\text { specimens }\end{array}$ & $\begin{array}{l}\text { hand sani- } \\
\text { tizing gel, } \\
\text { circulating } \\
\text { air dis- } \\
\text { infection } \\
\text { machine, } \\
\text { chlorine- } \\
\text { containing } \\
\text { disinfec- } \\
\text { tant, etc. }\end{array}$ & $\begin{array}{l}\text { After } \\
\text { age }\end{array}$ & us- \\
\hline
\end{tabular}




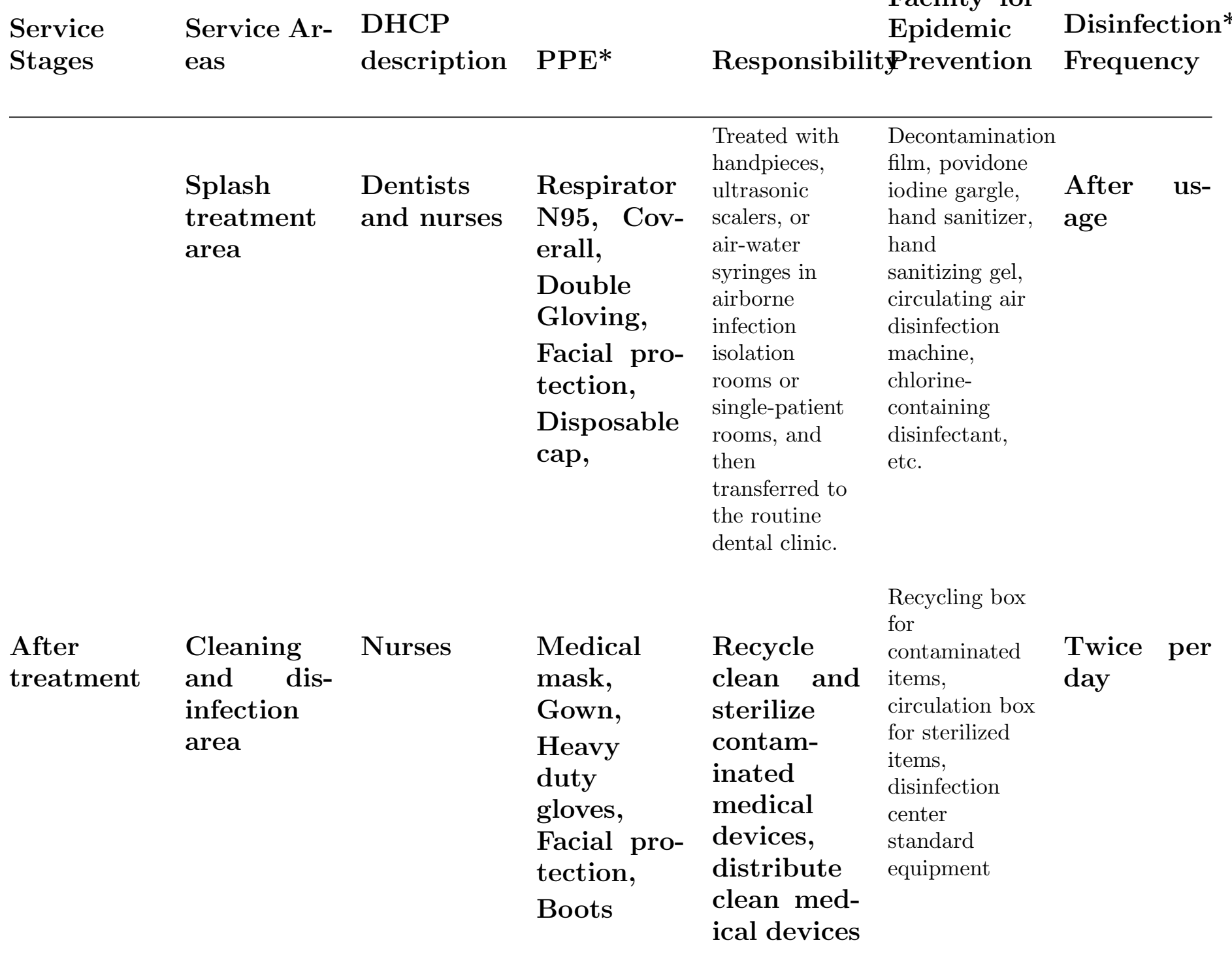


Service

Stages
Service Ar- DHCP

eas description $\mathrm{PPE}^{*}$
Facility for

Epidemic

ResponsibilitPrevention Frequency

$\begin{array}{llrl}\text { Pharmacy Pharmacist } & \begin{array}{l}\text { Medical } \\ \text { mask, }\end{array} & \begin{array}{l}\text { Distribution Hand san- Twice per } \\ \text { of various itizing gel, day } \\ \text { Gown, } \\ \text { medicines circulating }\end{array} \\ \text { Gloves, } & \begin{array}{l}\text { air dis- } \\ \text { Facial pro- }\end{array} \\ \text { tection, } & \text { infection } \\ \text { Disposable } & \text { chlorine- } \\ \text { cap } & \text { containing } \\ & \text { disinfec- } \\ & \text { tant, etc. }\end{array}$

**Clean and disinfect the room and equipment according to the Guidelines for Infection Control in Dental Health-Care Settings-2003.

Only patients with initial temperature measurement $<37.3^{\circ} \mathrm{C}$ can are allowed to enter the hospital. Patients with temperature [?]37.3degC or those with symptoms such as cough, sneezing, fatigue, or shortness of breath were transferred to the designated fever clinic for further check.

Health QR code: health information in WeChat app depending on big data technology, may recover epidemic clues efficiently.

\section{Hosted file}

2-figure1(1).eps available at https://authorea.com/users/337529/articles/463125-managementprotocol-for-dental-outpatient-department-during-the-covid-19-pandemic-documenting-bestpractices

\section{Hosted file}

3-figure2.eps available at https://authorea.com/users/337529/articles/463125-managementprotocol-for-dental-outpatient-department-during-the-covid-19-pandemic-documenting-bestpractices 
figures/4-figure3/4-figure3-eps-converted-to.pdf 
figures/5-figure4/5-figure4-eps-converted-to.pdf

\section{Hosted file}

6-Table1.docx available at https://authorea.com/users/337529/articles/463125-managementprotocol-for-dental-outpatient-department-during-the-covid-19-pandemic-documenting-bestpractices 